\title{
Unification and peace: How were the German churches involved in the search for unity to overcome conflicts of the last decades of the last century?
}

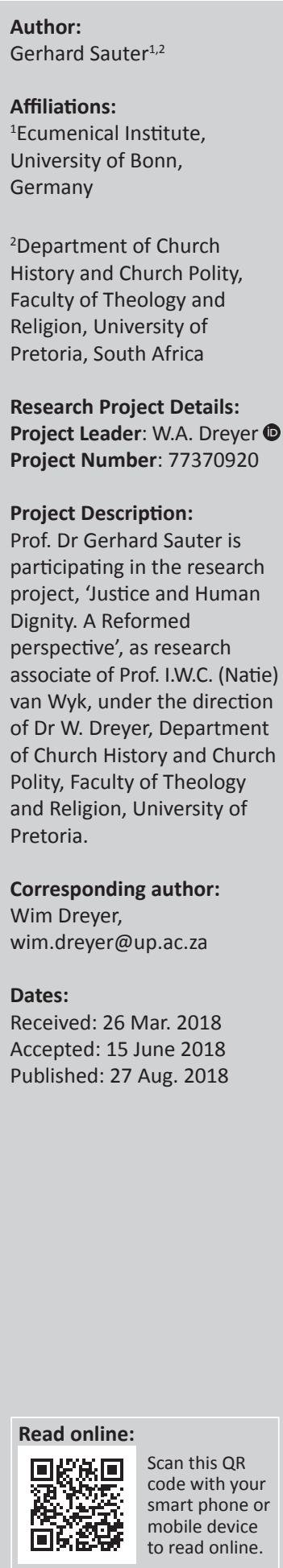

This article is a narrative reflection of the author's perspective on the role of the Church in the unification process of Germany in the last part of the last decade. It is presented from his perspective of being a German citizen, as well a member of the church in Germany. The author situates this experience amidst the political and ideological movements shaping the binary notions 'East' and 'West'.

\section{Introduction: Confronted with unexpected events}

On November 09 1989, the day the Berlin Wall collapsed, I was in Princeton (US) as a guest lecturer. In the late afternoon, by chance, I switched on the television set. To my wife's and to my surprise we saw people cheering and waving flags while standing on the wall. I assumed it was a new American movie and admired the excellent scenery in what I took to be a set. Then other guests of the house entered the room, embraced us, and congratulated Germany on such a miraculous event. We felt as if we were dreaming. Throughout the weeks before, many others and we had been afraid of political unrest and bloodshed. After all, there had been brutal repression in Beijing some months earlier. In early October we had just visited friends in East Germany. They were very concerned, particularly about the reaction of the government to the demonstrations and to the refugees trying to escape to West Germany via Czechoslovakia, Hungary and even Poland.

Now the Wall had fallen; the symbol of the Cold War had been removed. Some days later at the annual meeting of the American Academy of Religion, I heard an American theologian remark that he had had his doubts about the second coming of Jesus Christ, but not anymore. After the collapse of the Berlin Wall, he considered all things to be possible.

Was this an appropriate conclusion to draw from this event? As an event, it was no doubt both contingent and basically inexplicable. Of course, there were many attempts to account for what had happened. But I do not know of any serious politician, political expert, or journalist who can honestly claim that he or she had foreknown or predicted this event. After all, it is reasonable to have thought that there would have been an omen of some sort. To be sure, the end of the Cold War did not come down from heaven. A great many people played parts in very different and divergent ways, often unsuspectingly or even contrarily to their own intentions and plans. We can try to list these factors, but the event as such cannot be sufficiently explained (cf. Rödder 2009).

Which developments and changes had been thought to really be possible? It seemed sensible to expect at most a series of reforms in East Germany coming step by step and being politically achieved by opening the frontiers to the West with limited freedom for travelling, by allowing individuals to establish small businesses, by permitting independent workshops and trade, by increasing freedom of speech, and by ceasing political suppression of serious critics of the political system and of minorities, such as committed Christians. The vision was called 'democratic socialism' or 'socialism with a human face'. That meant a 'third way' in contrast to Western capitalism and its free market economy as well as to a communist state-owned and planned

How to cite this article: Sauter, G., 2018, 'Unification and peace: How were the German churches involved in the search for unity to overcome conflicts of the last decades of the last century?', HTS Teologiese Studies/Theological Studies 74(4), 4988. https://doi.org/10.4102/ hts.v74i4.4988

Copyright: @ 2018 . The Authors. Licensee: AOSIS. This work is licensed under the Creative Commons Attribution License. 
economy. Critical but loyal East German citizens viewed 'democratic socialism' as the chance for and openness to a truly friendly coexistence with East Germany's neighbours, especially with West Germany. West Germany would recognise the new democratic state, formerly called 'East Germany', as a relatively independent and reliable, selfsustaining state, but, as such, further integrated into the Eastern European distribution of production directed by the Soviet Union, and even incorporated in the military union of the Warsaw Pact in the hope that through reform this would become a purely defensive alliance.

This was even the vision of many East German citizens who were active in the movement for civil rights (Bürgerrechtsbewegung) that created local groups and networks of resistance against the suppression of civil rights nationwide during the late 1980s. These people were in fundamental agreement with socialism as a hopeful experiment for a world with more social justice and peace, but they opposed the repressive, even totalitarian, political system. At the same time, they did not want to be dependent on the Western system of a free market economy; instead, they wanted to search for an alternative to both: inhumane capitalism and the communist regulation of all parts of life. Many church groups shared this vision, and local churches such as the Nikolai Church in Leipzig and the Gethsemane Church in East Berlin became prominent as places that gave opportunity for a kind of public voice urgently demanding reforms. I will refer to this convergence of Christian engagement and the movement for civil rights later.

In 1989, many citizens and politicians in the West, even Chancellor Helmut Kohl of the Christian Democratic Union, had the same or a similar opinion concerning the desirability of the political development of two German states, with that of the East based on democratic socialism. It was hoped there would be a gradual economic stabilisation and improvement because East Germany had nearly been bankrupt already in 1987 and had survived only because West Germany had given enormous credits or loans and had paid a lot of fees for the Eastern highways and train connections between West Germany and West Berlin, as well as for other facilities. The Western government had been prepared to provide this and other kinds of support as the price of stabilisation and peace in the middle of Europe.

These were the main ingredients of the hope for an economic reform side by side with a gradual reform of the political system based on truly free elections with secret ballots. It was further hoped that these reforms would be coupled with a shift of mindedness in the way people conceived of social justice and with genuine, freely accepted democratic values, as against those merely indoctrinated by the Socialist Party and the communist state authorities. In hindsight, we can say that this vision underestimated the enormous costs of operating a vague, somewhat loose common identity divided into two German states. This vision required not only high economic costs but also changes in thinking and a farewell to the ideology of the Cold War and to the mutual condemnation of the different economic and political conditions. Were the people in both the East and the West prepared for such a kind of common identity?

In fact, most of them were not at all prepared for, nor capable of, this move. In November 1989 and during the following months, there was first a public outcry of demonstrators in the East: 'We are the people' - opposing the privilege of the socialist state and his supporting party to alone represent the people. Soon the slogan was changed into 'We are one people!' It was not said, 'We are one country', or even more, 'We are one nation'. When Chancellor Kohl heard the crowd in Dresden proclaiming, 'We are one people!' he perceived it as a cry for political, even national, unification but without any kind of nationalism or even chauvinism. Kohl realised that the vision of two German states had failed, and from that point he worked for political unification, accepting that an economic unification, or at least, the introduction of a common currency, would precede political change.

It may be argued that Kohl and many others only reacted to developments that seemed unavoidable. Afterwards, they saw that events had happened in a quite different way than they had intended. There seemed to be no time to spare on trying to unify minds. This unification was thought of as a fruit or side effect of the economic and political merger. A former chancellor, Willy Brandt, a prominent Social Democratic politician and previous mayor of West Berlin, phrased the quasi-biological slogan: 'It must grow together what belongs together!' ('Es muss zusammenwachsen, was zusammengehört!'). But in what respect did Germans in 1989 really belong together? In 1949, the 'Federal Republic of Germany' (Bundesrepublik Deutschland) in the West and the 'German Democratic Republic' (Deutsche Demokratische Republik, DDR) in the East had been founded. Germany seemed to be finally divided in a way that many thought of as the price of the lost war and a requirement for the complete collapse of National Socialism and German imperialism. Many Christians had seen the division of Germany as God's punishment of the German people. But others asked, 'Why are the East Germans more punished and have to pay a much higher price than the West Germans?' Subsequently, they viewed the political and economic, the psychological and even the spiritual costs of unification as a kind of compensation for the different burdens of East and West Germany.

Many prominent economists and trade and banking specialists warned against a premature economic unification that would neglect the immense differences between the social systems and conditions of productivity and trade in East and West Germany. They preferred a smooth transition from the socialist economy towards a moderate form of free economy. But the majority of the politicians in West Germany were afraid of a mass flight from the East to the West after the frontier had been opened, with the total collapse of East Germany as a consequence. Many were too optimistic or 
even euphoric regarding the real costs to be paid by the West German citizens. They trusted the process because they were caught up in a widespread enthusiasm about the unification, enormous economic growth following the tearing down of the Iron Curtain, and the change from the Soviet Union's being an enemy to being a partner of the 'free West'. Accordingly, in October 1990, political unification was accomplished only after some months full of excitement and turmoil. It was not at all a simple 'reunification', as many called it, comparing growing together with a somewhat natural healing process, but a 'welding together' of an apparently stable political system with a state in rapid transition or even in agony. And it was a fusion of two populations manifesting two different mentalities, two psychologically different realities and two different cultures, but with one apparently common language. After the first free election of the parliament of the unified Germany, sceptics said:

The East Germans elected the hard West German currency, the Deutsche Mark, hoping that nearly all other conditions of life would remain the same, especially the close-knit social security, the absence of unemployment, and other social achievements. They choose the Western economic standard without knowing its price.

In West Germany, many were convinced also that their own position would endure unchanged and that people in the East would be better off if they imitated the Western values. Some of our fellow people thought the Eastern population must follow us if we were to share some of our achievements with them. It was a mentality typical of glorious victors, but these winners had not really fought the decisive battle. These attitudes were a source of many misunderstandings and mistakes. In addition, most people in the West were not prepared for changes that happened all over Europe and worldwide (cf. Sauter 2008:23).

As far as I can see, only very few reckoned with the extent of another surprising, profound and far-reaching process: the implosion of the Soviet Union and the breakdown of the Soviet and Eastern European common market. Afterwards, it was mostly misjudged as a victory of Western expansive liberty, capitalism and free market economy. In fact, it was the result of inner paralysis, because the Soviet system had become hopelessly entangled in its own contradictions. One very important impact was a fading away of the mutual antagonism between the East and the West. This antagonistic orientation towards each other had influenced so much inner politics on both sides and had shaped the mentality of many people. Now there was a certain void. Some West German left-wing politicians talked of a 'peace dividend' that would be realised as military expenses were reduced. This was only a single error among many, but it showed the growing predominance of economic rationality.

It may be that catastrophes and defeats frequently lead to self-criticism and subsequent attempts to change previous behaviour. But why could not such a delightful surprise as the unification of Germany have encouraged a grateful amazement that would help provide a new basis for a fruitful unification, even a common identity? This task is the more urgent in a world where artificial amalgamations, often caused by geopolitical interests and backed by imperialism, collapse because they lack inner stability and strength.

\section{The unity of the church and contributions of German churches to unification}

Were the churches in Germany open-minded to the challenges of unification? Did they even contribute to the preparations for unification? Here, we must take into consideration some previous periods in the relationship between the government and the churches, especially in East Germany, and we must consider the answers given, direct as well as indirect, by the church officials, parishes and church members.

After World War II, the German churches remained among the few former institutions able to act together in all parts of the divided country, of course with many different restrictions because of the politics of the four victorious powers. As the Catholic dioceses saw themselves as members of a world church, they were more or less bound by the politics of the Vatican. Being a minority in East Germany, they were barely engaged in political or semi-political affairs there, in contrast to Poland where the powerful Catholic Church had been entitled to preserve Polish culture and identity since centuries.

Therefore, my following observations are concentrated on the Protestant churches in Germany. You will find the most prominent origins of Martin Luther's Reformation in East Germany, and this heritage includes many historic chance factors as well as burdens, including the interaction of 'state' and 'church' in the middle European countries which were united in 1871 in the German Empire. Later, German Protestantism was moulded by the clash with the church politics of the National Socialistic regime which was intensified in the so-called church struggle, especially in 1933/34. In 1945, after the end of the war, the 'Evangelical [that means: the Protestant] Church in Germany' (Evangelische Kirche in Deutschland, EKD) was constituted as an alliance of all regional Protestant Churches: the Lutheran, the Reformed and the United, a merger of Lutheran und Reformed Christians. 'Evangelical' and 'protestant' are synonymous terms; Methodists, Baptists and other denominations are called 'free churches'. Their composition is other than that of the Catholic and Protestant churches which are public corporations with a particular relationship with the state. The 'Evangelical Church in Germany' was not at all a national church organised as a unity, but a union of independent regional churches with one head: the elected leading 'Council' (Rat der Evangelischen Kirche in Deutschland) and the leading bishop.

After the War, all German Protestant churches understood themselves as united in many respects: as a community of faith, hope and love, trustful to the Holy Scripture. 
They shared a common spiritual history, theologically transformed. And they were bound together by the same complex and difficult history, especially by the burden of the National Socialist legacy. This self-understanding was exposed to the increasing division between East and West Germany, especially following 1949 when the two republics were established. The erection of the Berlin Wall in 1961 deepened the split enormously. Ideological contrasts intensified. Already in the 1950s many younger Christians in the East were excluded from higher education and discriminated against in many ways. Now, enclosed by the Berlin Wall and by the total fencing-in towards the West, non-conformists and faithful Christians felt more and more an overall repressive mood against all that was declared incompatible with the communist doctrine. This totalitarian enterprise asserted its unstoppable advance towards the radical change of the rest of the world through its transformation into a state of everlasting peace and justice according to socialist principles. The East Germany regime valued itself as 'real existing socialism'.

In 1968, the East German government declared that the frontiers of the country were also church borders according to the new constitution. The nine East German Protestant churches were required to leave the 'Evangelical Church in Germany' and constitute a new organisation. It was called the 'Alliance of Evangelical Churches in the DDR' (Bund Evangelischer Kirchen in der DDR), and was led by a bishop. In 1969 it emphasised in paragraph 4.4 of its 'church order':

The Alliance declares herself for the special community of the entire evangelical [body of] Christianity in Germany. Sharing the responsibility for this community, the Alliance undertakes tasks that are the shared concern of all evangelical churches in the German Democratic Republic and the Federal Republic of Germany through its authorities exercised within the freedom of partnership. $^{1}$

One of the main tasks was to give support to the diaconal ministry and to the social service of the churches (diakonia). In the East as well as in the West, there were hospitals, homes for disabled children and adults, retirement homes and other social facilities subsidised by the church but open to all people in need. This institutional social welfare work was one important bridge between West and East - and it is intact until today. It enabled the facilitation of a confidential exchange of different experiences and insights; for instance, in situations where the social welfare institutions of the church were able to help families to improve their endangered structures and to stand in where the socialist government was unable or unwilling to support emergencies. The continuing aid of the churches in the West plus donations from Western parishes and individuals strengthened this joint responsibility and led to lasting personal contacts, many of which are still vivid today.

1.Der Bund bekennt sich zu der besonderen Gemeinschaft der ganzen evangelischen Christenheit in Deutschland. In der Mitverantwortung für diese Gemeinschaft niment Christenheit in Deutschland. In der Mitverantwortung fur diese der Bund Aufgaben, die alle evangelischen Kirchen in der Deutschen Demokratischen Republik und der Bundesrepublik Deutschland gemeinsam beschäftigen, i partnerschaftlicher Freiheit durch seine Organe wahr (Henkys 1982:184).
The same was true on the local level: Western and Eastern parishes arranged partnerships. During the period of East Germany's isolation after 1961, many people suffered serious economic and psychic deprivation. The partnerships made it possible for others to know about these and make contact by parcels and letters. Families in Western parishes became close friends of Eastern families, even where it was not possible to meet or to call one another. Only later in the 1960s were citizens of the Federal Republic allowed to visit East Berlin, the capital city of East Germany. East Berlin became the most important meeting point, a place of reunion for at least a few hours. In the later 1970s Western citizens could not only be invited to visit their relatives in East Germany, but they could also travel there as tourists. East German citizens could get a travel visa only in very special cases. There were many other obstacles to making true partnerships possible and keeping them alive. Often letters and parcels did not reach their addressees; letters were intercepted and scrutinised. It required much patience and endurance to keep this modest token of unity afloat.

Another challenge to joint responsibility was the advance of aggressive atheism. The communist regime resumed the National Socialist attacks against the Christian faith, suppressing church activities where they seemed to interfere with the goals of communism. Many parishes in East Germany had to undergo significant changes because of the decrease of church membership. Shrinking parishes were united to larger ones, but little sub-parishes remained in rural villages with separate presbyteries. Under these circumstances, ministers were burdened with an excessive amount of management. On the other hand, basic democratic structures arose in presbyteries that enriched the life and work of the parishes. The situation of many endangered parishes in East Germany provoked Western partners to examine the validity of the life and work of their parishioners who were often inclined through indifference towards the soft atheism of some modern world-views and towards a materialistic way of life.

Most East German parishes provided more or less an open space for free speech and mutual understanding, very valuable in a society showered with ideological demands and guidelines that did not permit critical debate and required mere acclamation. However, the constitution of the German Democratic Republic (DDR) guaranteed the churches a certain freedom, restricted to religious matters of course. The limits of this freedom were defined in relation to the task of the Church, and were often exceeded. For example, when new Western popular music was not allowed in public, some parishes in larger towns permitted its performance in their rooms and even in the place of worship in order to allow the people to enjoy an atmosphere contrary to their often suppressed and depressing daily life, at least for some hours.

In the later 1970s and in the 1980s, many parishes facilitated the free exchange of information, especially concerning ecological requirements which were often neglected by the 
state officials. Another important concern among devoted Christians was the availability of civil service as an alternative to service in the army for conscientious reasons, similar to the regulations in the West German Federal Republic. In 1975 Erich Honecker, the head of the East German state, signed along with other state leaders the Helsinki Declaration which promised to respect human rights and basic freedoms. From that point more and more citizens, including Christians, made reference to this commitment. In the late 1980s protests increased over the denial of elementary civil rights like freedom of speech and liberty of information. People who were not privileged by the state were denied the liberty of travelling to foreign countries beyond the Eastern bloc. In May 1989, results of the municipal elections were forged. Many church members, ministers and church officials supported the public exposure of such deplorable state of affairs. Church meetings and synods expressed a well-founded critique and made detailed suggestions for improvement.

In the autumn of 1989, it emerged that the open space provided by the churches for free speech, free expression of opinion and exchange of substantiated information had prepared the groundwork for 'round table' talks that helped noticeably to develop the German revolution as a peaceful transformation. The local and regional round tables were symbols of equal rights for all their participants: members of the movement for civil rights, church members and ministers, artists, specialists of various fields who wanted to take responsibility for the common good and even leading members of the Socialist party who were open-minded about gradual reforms. The practice of the participants was to listen meticulously to one another, revise their presuppositions and be open minded in seeking unusual resolutions to problems. This was a decisive lesson for people in conflict situations.

The essential feature of the Christian commitment to unification may be demonstrated by a banner which was hung behind the altar in the Gethsemane Church in East Berlin during a so-called 'exhortation guard' (Mahnwache) in fall 1989 and was still to be seen there many years later, perhaps even today. It shows the abbreviated exhortation of Jesus to his disciples in the garden Gethsemane 'Keep watch and pray' (Matthew 26:41). Both are intertwined and cannot be divided in a political and spiritual dimension. Christians experienced the need to see clearly through a confusing situation and to pray for God's guidance on acting responsibly and on striving to tackle what is really needed at that point. This kind of prayer was and is the most helpful force for orientation according to faith and hope, as well as uniting faithful, expectantly watchful people in their cry for peace, justice and freedom. Protest Demonstrations like the 'Monday Demonstrations' in Leipzig since September 1989 started with prayer services in churches. A high-ranking member of the Socialist Party said: 'We were prepared for everything, but not for candles and prayers' (Wir waren auf alles vorbereitet, nur nicht auf Kerzen und Gebete). As much as anything, these prayers and activities may have helped to keep the German revolution non-violent - its outcome was by all means miraculous and the challenge remains to ascertain how far this was because of the forces of history.

What I have tried to sketch so far is only part of a complex picture of the ways of thinking and acting that characterised East German church members, ministers and partly church officials in a politically increasing dramatic situation. Their attitude must not be generalised. And not all of them were united in their intentions. There were tensions within the parishes concerning the essential tasks of the church. Ministers and church members who were persecuted for political reasons and wanted to oppose the aggressive and suppressing atheistic regime strictly speaking more often felt let down by church leaders. The space for critique was limited by compromises that church authorities had made with the authorities of the state. Members of the leading church bodies were also attracted by another seemingly unitive proposal introduced by some theologians in 1971 labelled 'Church within Socialism' (cf. Pollack 2001:1033-1035; Thumser 1996). This slogan was mostly understood as actually locating the church in a position that neither opposed socialism on principle nor unconditionally acclaimed it but enabled its participation in a truly socialist society. This understanding left space for a wide range of interpretations. As I mentioned earlier, many favoured a gradual reform of the East German 'status-quo socialism' (called 'real existing socialism') towards a 'democratic socialism'. Some related this vision to a famous phrase of Dietrich Bonhoeffer, the theologian and member of Resistance, killed by the Nazis: 'The Church is the Church only when it exists for others'.2 They regarded the task of the church as transcendence of former introverted religious habits and participation in humanitarian action. But they often neglected, I think, the truth that 'existing-forothers' is not possible in the long run without Christians existing 'with-each-other' and existing 'for-each-other' (Bonhoeffer 1996:170). Officials of the regime and church members misused the formula even to the point of committing the church to the socialist goal to radically change mankind and to create a new reality.

Altogether, it turned out that the slogan 'Church within Socialism' was ambiguous and confusing, but it functioned as a link between different opinions that converged in a mainly social and political idea of the church backed by some spiritual nourishment. Moreover, theologians and church leaders in West Germany, Western Europe and North America who leaned politically towards the left sympathised with the idea of a semi-utopian church within socialism. They saw churches in Eastern Europe as models for a future world church. The politics of the World Council of Churches (WCC) especially tended in that direction. Therefore, ecumenical representatives who visited socialist governed countries were often prejudiced. They were mostly informed by church

2.Unser Verhältnis zu Gott ist ein neues Leben im "Dasein für andere" in der Teilnahme ' 'Om Leben Jesu' (Bonhoeffer 1998:558). The Am "Dasein fuir andere," in der Teilnahme 'Our 'Our relation to God [...] a new "Tife for others, through participation in the Being of God' (cf. Bethge 1954:179); 'The Church is her true self only when she exists for humanity' (Bethge 1954:180; corrected in the 3rd edn.); 'The Church is the Church only when it exists for others' (Bethge 11954:211). See Krötke (1993:94-105). 
officials who affirmed more or less the politics of their state and did not allow sufficient scrutiny of the real situation of their fellow Christians. Therefore, the picture they perceived was a perverted one. Consequently, after 1989 and 1890 the WCC was unable to help reorganise distorted church structures in the former socialist countries.

\section{Success, failure and tasks}

On 03 October 1990, the unification of Germany was formally realised as a political decision of the two German parliaments, after the Eastern first free elections in May 1990. It was technically agreed that East Germany would join the Federal Republic of Germany and become fully integrated into the Federal Republic. This seemed to be the only realistic and best acceptable step to unite Germany. But what kind of unification was really promoted by this joining in? From the prevailing Western German point of view, applauded by the majority of East German people, the main political goal was to bring the basic living conditions of the East in line with the Western level or, at least, to bring them closer together. It was typical that the monetary union on 01 July 1990 preceded the political one, and the unions of economies and social orders were tackled at the same time. But as yet, after more than 25 years, the economic and social equalities have not been sufficiently accomplished in spite of assimilative growth in many fields. And some aspects of unification have been realised only superficially.

After the fall of the Berlin Wall a euphoric atmosphere was predominant in the whole of Germany. A spirit of extended liberty, the confidence in fair administration of justice and the feeling of unity prevailed. Not all things were possible, but much was. Hasty decisions and changes followed because there was no master plan for unification. Soon disappointment spread because many ambitions and hopes were not fulfilled.

In order to reach the goal of unification, first of all East German industry, farming, trade, administration, jurisdiction and higher education had to be reorganised to a large extent, mainly with the help of experts from the West. Many school teachers and university professors needed to be replaced, especially in the fields of history, social affairs and philosophy."

In general, the churches did not need such reorganisation, but they received new responsibilities beyond their former activities within the parishes and had to provide their members with sufficient preparation for these. For instance, they were invited to participate in religious education in public schools and to take on pastoral care in prisons. At the same time, it was discovered that in the church and in university departments of theology - just as in other institutions - some officials and employees had voluntarily or forcedly informed the state security service to various extents. And there had been some secret communication between members of the governing bodies of the churches and state officials (Besier 1995). Therefore, much confidence was lost and had to be built up from scratch. Nevertheless, the relationship between the parishes and the church government remained essentially intact, in contrast to Czechoslovakia, the Polish Lutheran Church and especially the Reformed Church in Hungary (Maser \& Holger Schjørring 2003), where church leaders had promoted a so-called 'theology of service' after the futile uprising of 1956, namely Christian stewardship as service to the people and, as such, supportive of the policy of the state (Szabó 1989:190-198).

The East German Protestant churches were again fully integrated in the Evangelical Church of Germany with their ruling bodies. Their 'special community' as emphasised in 1969 could be continued and improved by financial aid, support for new tasks and joint statements on urgent moral, social and political disputes. Ministers and other church members took on positions in public administration, parliament and government. Many of their abilities to manage serious restrictions, their experiences in conflict situations and their tried and tested judgements benefitted the unified Germany. The most prominent actual example is Joachim Gauck, the president of the Federal Republic of Germany 2012-17, a former minister, active in the civil rights movement, then member of the first free elected East German parliament, who headed the authority to put the documents of the East German state security service in the archives and to make them available.

Besides such positive, sometimes splendid examples of successful unification cases of incomplete and missing integration must not be overlooked. For example, East German parishes gained exemplary experiences of Christian life and testimony as a minority in an apathetic or hostile society. Christian education included learning the language of faith. Parishioners were engaged in preserving their often very old, mostly dilapidated churches which often had been partly destroyed by the war. Church members stayed together without cutting themselves off from their fellow citizens but tried to keep their facilities open for all people attracted by the church music that was very much rooted in this part of Germany or interested in the correlation of culture and Christian tradition. As a theologian, I thought highly of many Eastern friends and colleagues who were denied partnership in international exchange, had seldom access to many theological publications and journals and were severely limited in publishing their own articles and books. But that's exactly why they listened so precisely and worked so intensively in concentrating on the very essential questions. I admired the clarity of their judgement and their ability to deal with restrictions. Unfortunately, many of these and other qualities were not used to benefit Germany as a whole.

We must observe these disadvantages in a wider context. The unification started in a spirit of solidarity which was more emphatic than what was realised by the entry of East Germany into the Federal Republic. It was an affiliation, a technical taking over; not an occupation, but really a soft annexation that caused more disappointment and wounded 
self-esteem for many people. There was neither sufficient time nor the willingness to create a new constitution as such, but only some amendments to the constitution of the Federal Republic were added, mainly concerning the new size of Germany and its new frontiers. The same is true with regard to the system of law and rights and duties. Western firms and businesses, publishing houses and many newspapers took over their Eastern competitors.

Although many Eastern citizens would have been willing to contribute their expertise, skills and experiences to the new common identity, they felt such a contribution would not have been valued. I deeply regret that we Western citizens in general did not take much more serious account of this way of thinking. As far as I can see, there was, and continues to be, a lack of mutual respect as well as an insufficiently developed sense of reality in its various aspects. In West Germany, the predominant mentality was the illusion of being superior, caused partially by superficial visits and focusing on the well-known burden of many Eastern citizens. We must consider these problems as one of the constituents of the 'wall in the minds' after the break down of the physical barrier that had divided Berlin and the two German regions. The mental wall can be much more durable than an Iron Curtain.

\section{Conclusion: Two essential tasks - Cultural memory and language}

Firstly, unification was not based on a common German history; moreover, it was not supported by a common cultural memory of the most recent German history. Citizens in East and West differed significantly with regard to their conception of German history after World War II. East Germany had convinced itself that it had eradicated fascism completely. As it established a totally new political order, it did not feel any burden about the past, not even the guilt caused by the Holocaust, the Shoa. Astonishingly enough, in the 1970s and 1980s, there were signs of a rebirth of German nationalism in the East, made manifest in some patriotic attitudes that harked back to the advantages in the 18th and 19th centuries. In West Germany, from the late 1950s, there were often harsh disputes about what was happening during the first decade after the war. Given the heightening awareness of the burden of National Socialism and the Holocaust, many were aggrieved that elements of the previous regime were being restored. This concern became radicalised after 1968 in extreme forms, such as a generalised anti-patriotism or support only for 'patriotism of the constitution' (with all other kinds of identification with Germany and its history being blamed as nationalism). The orientation towards Western Europe and the United States, and especially the integration in the North Atlantic Treaty Organization (NATO), was controversial until the late 1980s.

In addition, there are, roughly speaking, two different conceptions of East German history, which still divide people in the eastern part of Germany today. It will be very challenging to convince the younger generation of the truth about the split of consciousness in recent German history and to establish (not to construct!) a common cultural memory of this history within the context of the many changes all over Europe and in other parts of the world. In this respect, it was probably providential that the unification of Germany took place alongside the broadening and unification of Europe. It shows that the German unification was not an isolated event but rather was woven into deep and farreaching developments that promote the possibility of common identity on a much larger scale.

Another serious obstacle to common identity was the difficulty in communicating the German language. In East Germany, the communist government and the Socialist party re-coined or reshaped the meanings of many everyday words. For example, 'solidarity' was restricted to meaning 'the support of communists and socialists' or 'the strengthening of the power of the working class'. 'Peace' was understood as a rigid defence of communism and, if necessary, as aggressive protection of the state of affairs of the socialist 'brother countries'. The totalitarian regulation caused many curious misunderstandings. When an invitatory poster for a regional church gathering referred to Revelation 1:8 'I am the A and the $\Omega$ ', says the Lord God' (which means, 'I am the beginning and the end of the alphabet', the symbol of all things), the police forbade this poster, arguing, "The A looks like "anarchy" and $\Omega$ is the abbreviation for "ohm," the symbol of one unit of electric resistance; therefore, the whole is an invitation to revolution!' The policemen did not know how right they were, but in quite another sense than they thought.

These examples are now out of date. But there are other semantic and syntactic differences between the German spoken in the East and that spoken in the West, mostly because of contextual peculiarities. For common identity to be finally achieved, fundamental agreement in the use of common language is required. As recent research shows, it will take a long, long time until this agreement is reached in the unified Germany (Reiher \& Baumann 2004; Reiher \& Läzer 1996; cf. Sauter 2008:21-23; Schlosser 1999). This agreement is even more urgent because of the flow of many refugees and immigrants to Germany over the last decades and just now.

Church and theology need a language that marks Christian identity as the community of faith, hope and love within a pluralistic society. It is not at all a pious jargon but a specific shape of terms, for example, freedom, justice, mercy, confidence, consolation and reconciliation. Where and how does this language interact with everyday language and is able to stimulate it?

I asked above if the unification of Germany could encourage a grateful amazement. Trust in God's acting on us, with us, against us and without us provokes us to watch and to pray. 
It may be that an element of such a profession is that we are reminded forcefully that God has the generosity and the sense of humour to know what to do with our doing, even with our wrongdoing, as well with our best prognoses, and with disappointment when these prognoses fail. God also knows what to do with our best intentions, even those that often have the opposite effect of what we intend. Do we not have reason to be surprised that we are still here, despite our doing? In recent years, I have often been reminded of Lamentations 3:

But this I call to mind, and therefore I have hope: The steadfast love of the Lord never ceases [Martin Luther's translation reads even stronger: 'The loving-kindness of God keeps us from being totally extinguished'3], his mercies never come to an end; they are new every morning; great is your faithfulness. (pp. 21-23)

With 'your faithfulness' the reflection turns into a prayer. God can make use of us if we are faithful and confident, open to surprises and capable of new beginnings.

In view of the unified Germany, one of the most burdensome factors that continues to hinder the achievement of a vivid and promising unity is that it is extremely difficult for most Germans to become really reconciled to the reality of the 12 cruel years of terror, murder and segregation caused by the Nazi regime, together with the consequences of this for the following five decades. There have been many successful endeavours to reconcile Germany with its neighbours, mainly on economic and geopolitical terms. But the spiritual depth of God's reconciliation of the world with him is widely unknown or reduced to the restoration of wounded relations.

The German churches contributed decisively to achieving an identity not on the basis of an economic merger or a political union with all the complications and psychological costs that the German experiences show, but rather on the basis of their participation in God's creative forgiveness, atonement and mutual reconciliation. This would include not only being compassionate but merciful with each other in the light of their different and complicated recent stories to the point of

3.Luther refers to God's tireless acting that not only promises the continuity of God's creation but also revives fatally afflicted or even dying people and creates 'a new thing' (Is 43:19). being able to hear and to confirm in a reconciling way to each other the apostolic message:

In Christ God was reconciling the world to himself, not counting their trespasses against them, and entrusting the message of reconciliation to us. So we are ambassadors for Christ, because God is making his appeal through us; we entreat you on behalf of Christ, be reconciled to God. (2 Cor 5:19-20)

in order to become reconciled with each other.

\section{Acknowledgements Competing interests}

The author declares that he has no financial or personal relationships which may have inappropriately influenced him in writing this article.

\section{References}

Besier, G., 1995, Der SED-Staat und die Kirche 1969-1990: Die Vision vom Dritten Weg, Propyläen, Frankfurt am Main.

Bethge, E. (ed.), 1954, Prisoner for God: Letters and papers from prison, transl. R.H. Fuller, Macmillan, New York.

Bonhoeffer, D., 1996, 'Sanctorum Communio: A theological study of the sociology of the church', in C.J. Green (ed.), Dietrich Bonhoeffers works, vol. 1, transl. R. Krauss \& N. Lukens, pp. 170-175, Fortress Press, Minneapolis, MN.

Bonhoeffer, D., 1998, Widerstand und Ergebung: Briefe und Aufzeichnungen aus der Haft in Werke, vol. 9, Chr. Kaiser Verlag, Gütersloh.

Henkys, R. (ed.), 1982, Die Evangelischen Kirchen in der DDR: Beiträge zu einer Bestandsaufnahme, Chr. Kaiser Verlag, München.

Krötke, W. 1993 "Dietrich Bonhoeffer als "Theologe der DDR": Ein kritischer Rückblick', Zeitschrift für Evangelische Ethik 37, 94-105.

Maser, P. \& Schjørring, J.H. (eds.), 2003, Wie die Träumenden? Protestantische Kirchen in der Phase des Zusammenbruchs der kommunistischen Herrschaft im östlichen Europa, Martin-Luther-Verlag, Erlangen.

Pollack, D., 2001, 'Kirche im Sozialismus', in H.-D. Betz et al. (eds.), Religion in Geschichte und Gegenwart [RGG ${ }^{4}$ ], 4th edn., vol. 4, pp. 1033-1035, MohrSiebeck, Tübingen.

Reiher, R. \& Baumann, A. (eds.), 2004, Vorwärts und nicht vergessen: Sprache in der $D D R$ - Was war, was ist, was bleibt, Aufbau Taschenbuch Verlag, Berlin.

Reiher, R. \& Läzer, R. (eds.), 1996, Von 'Busch-Zulage' und 'Ossinachweis': Ost-WestDeutsch in der Diskussion, Aufbau Taschenbuch Verlag, Berlin.

Rödder, A. 2009, Deutschland einig Vaterland: Die Geschichte der Wiedervereinigung [Germany - United Fatherland: The history of reunification], C.H. Beck, München.

Sauter, G., 2008, 'What does common identity cost? Some German experiences and provocative questions', in S.C.H. Kim, P. Kollontai \& G. Hoyland (eds.), Peace and reconciliation. In search of shared identity, pp. 21-34, Routlegde, London.

Schlosser, H.D., 1999, Die deutsche Sprache in der DDR zwischen Stalinismus und Demokratie: Historische, politische und kommunikative Bedingungen, 2nd edn. Verlag Wissenschaft und Politik, Cologne (Köln),

Szabó, I., 1989, 'A long period of inner bleeding: The theology of service as the reflection of the miseries of the reformed church in Hungary', Kirchliche Zeitgeschichte/Contemporary Church History 2, 190-198.

Thumser, W., 1996, Kirche im Sozialismus, MohrSiebeck, Tübingen. 